\title{
Peran Kaum Milenial sebagai Cross-Cutting Interpreters dalam Pengembangan Desa Wisata Pelaga Kabupaten Badung Bali
}

Fransisco Situmoranga,1, Saptono Nugroho ${ }^{a, 2}$

1 fransiscositumorang41@gmail.com, ${ }^{2}$ saptono_nugroho@unud.ac.id

a Program Studi S1 Destinasi Pariwisata, Fakultas Pariwisata,Universitas Udayana, Jl. Dr. R. Goris, Denpasar, Bali 80232 Indonesia

\begin{abstract}
The economic disparity that occurred in Badung Regency, Bali was caused by the rapid development of tourism that does not align with the development of the agricultural sector in the north. This then pushed the Pelaga Tourism Village millennial to urbanize into the southern regions to continue education and to obtain employment. This research aims to analyze the role that millennials can do as cross-cutting interpreters in the development of Pelaga Tourism Village. This research uses qualitative data with two data sources: primary data and secondary data. The data collection techniques used in this research are library studies, observations, interviews, and documentation. In determining the informants is used as a purposive sampling technique. In this study, the data analysis technique used is descriptive-qualitative. The results showed that the role of the millennial generation in the development and management of tourism villages has been very minimal. This is very unfortunate considering the millennial has the ability as cross-cutting interpreters and as well as rich in innovation and much-needed creativity in the development of tourism villages. The role that can be performed by millennials in developing tourist villages is by establishing BUMDes as an organization for tourism village management. Millennials should also conduct mapping and development of several tourism potentials in each Banjar by prioritizing the aspect of diversification. At the marketing and promotion stage, millennials who are technologically literate can utilize digital media as a means to introduce and offer tourism products.
\end{abstract}

Keyword: Millenials, Cross-Cutting Interpreters, Tourism Villages

\section{PENDAHULUAN}

Pemerintah Indonesia pada tahun 2015 menetapkan sektor pariwisata sebagai salah satu dimensi sektor unggulan dalam kerangka agenda pembangunan nasional atau yang lebih lazim dikenal sebagai Nawacita Jokowi-JK 2015-2019 (bumdes.id : 2019, kemenpar : 2018). Hal ini mendorong adanya akselerasi pengembangan dan pembangunan kepariwisataan hampir di seluruh wilayah Indonesia yang dilakukan oleh sejumlah stakeholder pariwisata.

Pada tahun 2019, Kementerian Pariwisata menargetkan 20 juta jumlah kunjungan wisatawan mancanegara. Untuk merealisasikan hal tersebut, pengembangan sejumlah destinasi berdasarkan aspek potensi alam, budaya, dan buatan terus gencar digalakkan (Kementerian Pariwisata : 2017). Di tahun 2018, pemerintah berfokus pada pelaksanaan program pengembangan 2.000 desa wisata yang tersebar di 14 provinsi. Hal ini bertujuan untuk merealisasikan 1,9 juta target kunjungan wisatawan mancanegara ke wilayah perdesaan sebagaimana telah ditetapkan pada aspek portofolio pariwisata.

Bali merupakan salah satu provinsi yang ditetapkan dalam pengembangan desa wisata tersebut. Penetapan provinsi dengan brand pariwisata "the island of Gods" ini tidak terlepas dari sejumlah potensi pariwisata yang dimiliki. Bali yang sudah menggeluti dunia kepariwisatan selama lebih seratus tahun ini juga telah menjadi destinasi wisata yang paling banyak dikunjungi wisatawan mancanegara (Anom, dkk., 2017). Terbukti, pada tahun 2017 lalu, pulau seribu pura ini berhasil mendatangkan 5.381 .828 wisatawan mancanegara atau sekitar $40.52 \%$ dari total kunjungan wisman ke Indonesia (bps.go.id, 2018 ; tempo.co, 2018 ; tribunnews.com, 2018). Kemudian, di tahun 2018, Bali dikunjungi oleh 6.070.473 wisatawan mancanegara atau sekitar $38,4 \%$ dari total kunjungan ke Indonesia (bali.tribunnews.com : 2019, bali.bps.go.id : 2019).

Pengembangan desa wisata di Bali sebenarnya bukan merupakan hal baru. Jauh sebelumnya, Pemerintah Provinsi Bali, khususnya Kabupaten Badung sudah menggarap hal yang sama sejak tahun 2010 lalu melalui Surat Edaran Kepala Dinas Pariwisata Daerah Povinsi Bali Nomor 556/317/I/DISPAR tentang Pengembangan 100 Desa Wisata 2014-2018 dan Peraturan Bupati Badung Nomor 47/2010 tentang Penetapan Kawasan Desa Wisata di Kabupaten Badung. Adapun sejumlah desa wisata yang ditetapkan di Kabupaten Badung, yakni, 
Desa Kapal, Desa Mengwi, Desa Baha, Desa Munggu, Desa Bongkasa Pertiwi, Desa Sangeh, Desa Carangsari, Desa Pangsan, Desa Petang, Desa Pelaga, dan Desa Belok Sidan (Mahagangga, dkk., 2015).

Pengembangan sebelas desa wisata ini dilakukan sebagai upaya untuk mengatasi kesenjangan yang terjadi di Kabupaten Badung bagian utara dan selatan. Kesenjangan tersebut merupakan konsekuensi dari pembangunan kepariwisataan yang selama ini terkonsentrasi di wilayah selatan sebagai trade mark pariwisata Bali, seperti Nusa Dua, Uluwatu, Jimbaran, Seminyak, Canggu, dan sebagainya. Sementara itu, wilayah utara yang memiliki potensi pariwisata yang cukup besar hanya dimanfaatkan sebagai kawasan konservasi, daerah resapan air, dan pertanian terintegrasi. Nilai-nilai tradisi masyarakat lokal yang masih dilestarikan serta kondisi eksisting alam yang masih asri dan alami dianggap sangat potensial untuk dikembangkan guna meminimalisir dampak negatif pariwisata (Anom, dkk: 2015 ; Perda Kabupaten Badung Nomor 26/2003). Sehingga, dewasa ini, Kabupaten Badung terpolarisasi menjadi dua dalam merekonstruksi pariwisata, yaitu bagian utara sebagai alternative tourism dan bagian selatan sebagai mass tourism (Nugroho dan Palguna, 2016).

Pada praktik pengembangan kesebelas desa wisata tersebut, Nalayani (2015) menyebutkan bahwa hanya terdapat dua desa wisata yang dapat dikatakan telah berkembang, yaitu Sangeh dan Bongkasa Pertiwi. Sementara desa lainnya masih dalam tahap pengembangan, bahkan ada pula yang masih dalam fase 'embriotik'. Sebagai desa wisata yang dikatakan belum berkembang, praktik kepariwisatan di Desa Pelaga sebenarnya sudah dimulai sejak tahun 1999. Pada masa itu, Yayasan Wisnu melakukan pemetaan terhadap sejumlah desa di Bali yang berpotensi untuk dikembangkan sebagai ekowisata. Hasilnya, terdapat empat desa yang dinyatakan layak, yakni Desa Pelaga (Badung), Desa Sibetan (Karangasem), Desa Tenganan (Karangasem), dan Desa Nusa Ceningan (Klungkung) yang secara bersama-sama sepakat untuk membentuk organisasi "Jaringan Ekowisata Desa" (JED). Organisasi ini memiliki tujuan untuk membangun dan mengembangkan ekowisata berbasis masyarakat lokal dan keberlanjutan lingkungan di keempat desa tersebut (Saragih, dkk : 2015). Meski telah berjalan selama dua puluh tahun namun sektor pariwisata masih belum mampu memberikan kontibusi ekonomi secara positif bagi masyarakat setempat. Hal ini umumnya terjadi karena sejumlah kendala, seperti kekurangan sumberdaya manusia yang berkualitas, rendahnya pengetahuan dan partisipasi masyarakat lokal dalam pengelolaan desa wisata, minimnya promosi pariwisata yang dilakukan, pendanaan dari pemerintah yang terbatas, tidak ada target pasar, diversifikasi produk wisata yang cenderung sama dengan desa wisata lainnya, dan sebagainya (Anom, dkk : 2015).

Oleh karena itu, penelitian ini dimaksudkan untuk memberikan solusi berupa rekomendasi kebijakan bagi Desa Wisata Pelaga dalam menangangi permasalahan terkait dengan promosi dan pemasaran produk pariwisata. Penelitian ini juga bertujuan untuk membangun partisipasi masyarakat dalam pengelolaan desa wisata, secara khusus bagi kaum milenial desa.

\section{TINJAUAN PUSTAKA}

Telaah hasil penelitian sebelumnya dilakukan sebagai acuan untuk menentukan posisi atas fokus kajian yang akan dilakukan dalam penelitian saat ini. Penelitian pertama dilakukan oleh Anom (2015) dengan judul "Peluang, Tantangan, dan Strategi Pengembangan Desa-Desa Wisata di Kabupaten Badung". Penelitian ini bertujuan untuk mengkaji potensi pariwisata, kendala, dan strategi pengembangan desa wisata di Kabupaten Badung yang dapat dilakukan oleh pemerintah maupun masyarakat lokal. Adapun strategi pengembangan Desa Wisata Pelaga yang diusulkan dalam penelitian ini diantaranya, penyiapan lahan untuk pusat pengembangan desa wisata, pengembangan pondok wisata yang dimiliki dan dikelola masyarakat lokal, memuat aturan khusus untuk meminimalisir alih fungsi lahan, pengembangan ekowisata berbasis kearifan masyarakat lokal, dan pengembangan kualitas sumberdaya manusia.

Penelitian kedua berjudul "Peran Kaum Milenial dalam Pengembangan Digital Nomadic Tourism sebagai Badan Usaha Milik Desa : Studi Kasus pada Desa Wisata Pelaga Kabupaten Badung Bali“. Hasil penelitian ini menawarkan usulan pengembangan digital nomadic tourism sebagai BUMDes yang dapat dilakukan oleh kaum milenial untuk membangun peran mereka dalam penyediaan lapangan pekerjaan dan peluang usaha baru di Desa Wisata Pelaga. Perlu diketahu bahwa penelitian pada saat ini merupakan lanjutan dari penelitian terdahulu untuk menyempurnakan kekurangan yang ada.

Penelitian terakhir dilakukan oleh Nugroho dan Palguna (2015) yang berjudul "Generasi Muda dalam Praktik Desa Wisata di Kabupaten Badung". Hasil penelitian menunjukkan bahwa adanya konsepsi ageism, tafsir eksternal, dan tafsir internal menjadi faktor utama yang menyebabkan minimnya peran kaum milenial 
dalam pengelolaan desa wisata di Kabupaten Badung. Sehingga diperlukan adanya strategi pelembagaan di tingkat desa wisata dengan memberi kesempatan bagi kaum milenial untuk turut berpartisipasi dalam kelembagaan tersebut.

Pada penelitian ini, digunakan empat konsep untuk menganalisis data yang diperoleh. Adapun konsep tersebut, yaitu Desa Wisata, Kaum Milenial, Cross-Cutting Interpreters dan Viral Marketting.

\section{Desa Wisata}

Desa wisata merupakan sebagian atau keseluruhan kawasan pedesaan yang memiliki potensi, aktivitas, produk dan diintegrasikan dengan akomodasi serta fasilitas pendukung lainnya untuk pengembangan pariwisata. Hal diatas dikemas menjadi rangkaian produk pariwisata yang dikelola secara berkelanjutan oleh masyarakat lokal dengan mencerminkan keseluruhan suasana dengan menonjolkan kearifan, keaslian, keunikan, arsitektur bangunan, tata ruang desa, dan sebagainya (Anom, dkk: 2015 ; Nuryanti: 1993 ; Sanjiwani: 2015 ; Suryawan, dkk: 2015).

\section{Kaum Milenial}

Kaum milenial yang disebut juga sebagai generasi Y dan/atau digital generation ialah individu yang lahir dari tahun 1980-1990 atau yang saat ini berusia 16-36 tahun. Generasi ini tumbuh seiring dengan perkembangan teknologi dan internet dan dianggap sebagai generasi modern yang aktif bekerja, penelitian, memiliki pola pikir inovatif tentang organisasi, optimis, serta memiliki kemauan untuk bekerja secara kompetitif, terbuka dan fleksibel (Putra, 2016 ; Anonim, 2017; Pratseyani, 2017; mentalfloss.com, 2019 ; Frey, 2018).

\section{Cross-Cutting Interpreters}

Cross-cutting actor merupakan kelompok yang mampu bertemu dan diterima oleh semua pemangku kepentingan pariwisata baik di internal desa wisata maupun dengan pihak eksternal, seperti wisatawan, pemerintah daerah, pihak swasta (investor) maupun kelompok kepentingan tertentu. Karena dapat diterima oleh semua pihak, kaum milenial juga memiliki peran sebagai sang penafsir (interpreter group). Perkawinan kedua konsep ini akan menjadikan kaum milenial sebagai actor cross-cutting interpreter atau penafsir pelintas batas (Nugroho dan Palguna, 2016).

\section{Viral Marketing}

Viral marketing merupakan bentuk pemasaran dari mulut ke mulut berbasis internet (e-word of mouth marketing) yang fungsi promosinya bersifat networking dan dirancang seperti virus berjangkit dari satu orang ke orang lainnya secara cepat dan luas.Adapun media yang dapat digunakan dalam viral marketing ialah, $e$ mail, situs jejaring sosial, video viral, dan $e$-book viral. Secara stuktur dasar viral marketing dibedakan menjadi, (1) Active Viral Marketing yang diasosiasikan dengan konsep tradisional word-of-mouth karena pemakai bisasanya terlibat secara personal dalam proses menjaring konsumen baru. (2) Frictionless Viral Marketing yang tidak mensyaratkan partisipasi aktif dari konsumen untuk mengiklankan atau menyebarkan informasi suatu produk. Dalam hal ini, dorongan awal untuk promosi viral didahului oleh pihak perusahaan pembuat produk itu sendiri (Achyunda, dkk: 2017; Andini, dkk: 2014; Situmorang, 2010).

\section{METODE PENELITIAN}

Penelitian ini berlokasi di Desa Wisata Pelaga, Kabupaten Badung, Bali yang dilakukan sejak bulan April 2018 sampai bulan Mei 2019. Penelitian ini menggunakan data kualitatif yang diungkapkan dalam bentuk kalimat serta uraianuraian (Bungin, 2007). Untuk memperoleh data, penelitian ini menggunakan dua sumber, yaitu data primer yang diperoleh secara langsung saat melakukan penelitian dan data sekunder yang diperoleh dari berbagai sumber bacaaan, seperti jurnal, skripsi, buku, dan sebagainya (Kusmayadi dan Sugiarto, 2000 ; Moleong, 2012). Data diperoleh melalui studi kepustakaan, observasi, wawancara, dan dokumentasi (Bungin, 2007; Moleong, 2014; Sugiyono, 2013). Informan dalam penelitian ini ditentukan melalui metode purposive sampling dengan 6 orang informan yang terdiri dari Ketua Kelompok Sadar Wisata, Ketua Karang Taruna, Manajer Bagus Agrowisata Pelaga, Anggota STT Banjar Tinggan, Anggota STT Banjar Pucak Tinggan, Pengelola Bali Jhon Swing, Petugas Loket Air Terjun Nungnung. Untuk menganalisis data digunakan teknik deskriptifkualitatif yang menggambarkan suatu fenomena kemudian mengaitkannya dengan fenomena lain melalui interpretasi untuk dideskripsikan dalam satu kualitas yang mendekati kenyataan (Muhadjir, 1996).

\section{HASIL DAN PEMBAHASAN}

Kesejangan perekonomian yang terjadi di Kabupaten Badung terjadi karena adanya konsentrasi pusat pertumbuhan ekonomi di wilayah selatan sebagai sentra pariwisata. Dengan dalih untuk memenuhi kebutuhan wisatawan yang terus meningkat, pembangunan fasilitas umum maupun fasilitas pariwisata tidak pernah absen dilakukan. Hal ini kemudian mendorong sektor pariwisata di Kabupaten Badung, khususnya wilayah selatan sebagai kontributor terbesar bagi Pendapatan Asli Daerah (BPS Provinsi Bali, 2018 ; 
badungkab.go.id : 2019). Bahkan, sekitar 90\% masyarakat di wilayah selatan sangat bergantung pada sektor pariwisata dan jasa sebagai mata pencaharian utamanya (Mahagangga, dkk : 2015). Sementara itu, wilayah utara sebagai kawasan pertanian terintegrasi tidak mengalami perkembangan yang cukup signifikan layaknya sektor pariwisata di wilayah selatan. Akibanya, terjadi ketimpangan tingkat pendapatan masyarakat, disparitas pembangunan, konsentrasi lapangan pekerjaan, kesenjangan peluang usaha, dan sebagainya.

Menurut Situmorang dan Narottama (2019), hal ini kemudian berimplikasi secara langsung terhadap praktik urbanisasi yang terjadi di Desa Wisata Pelaga. Terdapat sekitar 70\% kaum milenial yang berurbanisasi untuk melanjutkan pendidikan maupun bekerja di wilayah selatan sementara sisanya masih menetap di desa dengan status sebagai pelajar dan petani. Minimnya lapangan pekerjaan dan adanya penawaran upah yang lebih tinggi di wilayah selatan diakui sebagai salah satu faktor utama yang mendorong praktik urbanisasi oleh kaum milenial. Menyimak fakta tersebut, tidak mengherankan jika peran dan partisipasi kaum milenial dalam pengelolaan desa wisata masih sangat rendah.

Fakta lain juga diungkapkan oleh Nugroho dan Palguna (2016) yang menjelaskan bahwa minimnya partisipasi kaum milenial dalam pengelolaan desa wisata di Kabupaten Badung disebabkan atas 3 faktor. Pertama, adanya konsepsi ageism oleh kalangan senior yang memandang kaum milenial terlalu muda, kurang mampu dan belum matang, serta masih terlalu emosional dalam pengelolaan desa wisata. Kedua, kaum milenial kerap dibutakan dalam perangkap modernitas yang menawarkan kamuflase dalam bingkai hidup konsumerisme. Sehingga, kaum milenial menjadi kurang percaya diri dalam mengaktualisasikan diri secara autensitas berbasis kearifan budaya lokal karena mereka telah terbawa arus kapitalisme global. Ketiga, adanya kekeliruan dalam memaknai suatu pekerjaan. Kaum milenial cenderung memandang suatu pekerjaan sebagai ruang untuk memenuhi kebutuhan ekonomi bukan sebagai wadah untuk berekspresi dan berkreativitas. Implikasinya, mereka lebih memilih untuk mencari pekerjaan ke kota daripada mengembangkan potensi ekonomi yang ada di desa. Hal ini tentunya terjadi karena kekeliruan tersebut yang telah menumpulkan kreativitas mereka.

Realitas ini sangat disayangkan menimbang kaum milenial dianggap sebagai cross-cutting actor dengan stamina yang lebih prima, akrab dengan kecanggihan teknologi, menyukai tantangan dan hal-hal baru, serta cenderung bebas dari kepentingan politis praktis. -cutting interpreter atau penafsir pelintas batas (Nugroho dan Palguna, 2016). Momentum pengembangan desa wisata inilah yang sepatutnya dimanfaatkan oleh kaum milenial dalam menunjukkan eksistensi dan keterlibatannya.

Sebagaimana diketahui bahwa kebijakan pengembangan desa wisata ini dapat dikategorikan sebagai produk pariwisata yang ekslusif. Alasannya ada tiga, yaitu pertama, kebijakan ini lahir dan dijalankan atas kolaborasi antartiga kementerian, yaitu Kementerian Pariwisata, Kementeria Desa dan PDTT serta Kementerian Koperasi dan UMKM. Kolaborasi ini kemudian dikenal sebagai istilah Indonesia Intercorporated. Kedua, pengembangan desa wisata juga dimaksudkan sebagai upaya untuk mewujudkan tiga dari sembilan poin dalam Nawacita yang menjadi agenda pemerintahan Jokowi-JK. Adapun ketiga poin tersebut, diantaranya (3) membangun Indonesia dari pinggiran dengan memperkuat daerah-daerah dan desa dalam kerangka negara kesatuan; (6) meningkatkan produktivitas rakyat dan daya saing di pasar Internasional sehingga bangsa Indonesia bisa maju dan bangkit bersama bangsabangsa Asia lainnya; (7) mewujudkan kemandirian ekonomi dengan menggerakkan sektor-sektor strategis ekonomi domestik (bumdes.id : 2019, Tim Percepatan Wisata Desa dan Kota, 2017). Ketiga, pengembangan desa wisata merupakan wujud implementasi nyata dari Undang-Undang Nomor 6 Tahun 2014 tentang Desa yang memberikan kewenangan bagi desa dalam menentukan peran, posisi, dan kewenangannya sendiri. Desa yang selama ini hanya berkedudukan sebagai objek kini bertransformasi menjadi subjek pembangunan sebagaimana untuk mendukung Nawacita poin ketiga (Kurniawan; 2015). Pembangunan desa dianggap memiliki peranan penting dalam pembangunan nasional dikarenakan penduduk Indonesia cenderung bermukim di desa sehingga akan membawa pengaruh besar terhadap stabilitas ekonomi (Sa'dullah : 2016 dalam Agunggunanto, dkk : 2016).

Minimnya sumberdaya manusia yang berkualitas merupakan salah akar permasalahan dari sejumlah kendala pengembangan Desa Wisata Pelaga maupun desa lainnya di Kabupaten Badung. Sehingga, keterlibatan kaum milenial dalam pengelolaan desa wisata sangat dibutuhkan. Generasi yang identik dengan semangat tinggi, penuh kreativitas, kaya inovasi, berpikiran terbuka, dan berwawasan luas ini diharapkan mampu memberikan perubahan bagi Desa Wisata Pelaga. Hal ini didukung pula dengan realitas bahwa kaum milenial yang berurbanisasi ke wilayah selatan umumnya bekerja pada sektor 
pariwisata, seperti waiter/waitress, kapal pesiar, chef, pegawai hotel/ kafe/ restoran, dan sebagainya. Beberapa diantara mereka juga merupakan pelajar dan mahasiswa yang menempuh pendidikan di bidang parwisata. Sehingga, sedikit banyaknya, mereka sudah memahami karakteristik, tipologi, dan preferensi wisatawan. Dengan begitu, kaum milenial ini pun akan mampu melakukan segmentasi pasar yang diharapkan.

Dengan begitu, kaum milenial sudah sepatutnya kembali ke desa untuk menciptakan peluang usaha dan lapangan pekerjaan, tidak lagi sebagai pencari kerja. Sebagai tombak pembangunan desa, kaum milenial harus mampu melawan konsepsi ageism yang ditujukan kepada mereka dan merubah cara pandang dalam menyikapi dunia kerja. Salah satu langkah awal yang dapat dilakukan oleh kaum milenial dalam pengelolaan desa wisata adalah memainkan peran mereka sebaga cross-cutting interpreter. Artinya, kaum milenial yang diterima oleh seluruh elemen ini berperan untuk memecah kebekuan dan kebuntuan komunikasi antar pemangku kepentingan pariwisata. Berdasarkan hasil temuan di lapangan, pengelolan Desa Wisata Pelaga masih sangat minim sinegritas antar pemangku kepentingan dan pelaku pariwisata. Hal ini dapat dilihat dari pengelolaan sejumlah daya tarik wisata maupun fasilitas pariwisata yang dilakukan oleh masing-masing banjar. Sebut saja, Banjar Tinggan yang sejak tahun 2017 dikembangkan sebagai desa wisata oleh salah satu bank swasta manakala wilayahnya secara de facto merupakan bagian dari Desa Wisata Pelaga. Air terjun Nunggung dikelola oleh Banjar Nunggung tanpa memiliki keterkaitan dengan Desa Wisata Pelaga, pendirian pondok-pondok wisata secara perorangan, begitu juga dengan penjualan paket wisata oleh organisasi JED yang hanya terfokus di Banjar Kiadan. Selain itu, terdapat beberapa daya tarik wisata yang dikelola secara murni oleh pihak swasta, seperti Bagus Agro Pelaga, Bali Jhon Swing, dan pendirian pabrik wine yang kurang melibatkan partisipasi masyarakat sekitar.

Melalui keterlibatannya, kaum milenial dapat mencairkan ego sektoral terkait pengelolaan daya tarik wisata di setiap banjar dan merekonstruksi sinegritas antar stakeholders (Nugroho dan Palguna, 2015). Mereka juga akan menciptakan suatu sistem yang terintegritas antar stakeholders, baik itu pemerintahan desa maupun antar pengelola daya tarik wisata, pelaku usaha pariwisata maupun organisasi kemasyarakatan di tingkat desa dan banjar. Untuk menjamin adanya sinergitas tersebut, kaum milenial dapat mengajukan pembentukan Badan Usaha Milik Desa (BUMDes) sebagai organisasi pengelola desa wisata yang memanfaatkan alokasi dana desa. BUMDes merupakan badan usaha yang seluruh atau sebagian besar modalnya dimiliki oleh desa melalui penyertaannya secara langsung yang berasal dari kekayaan desa yang dipisahkan guna mengelola asset, jasa pelayanan, dan usaha lainnya untuk sebesar-besarnya kesejahteraan masyarakat Desa (UU 6/2014 tentang Desa).

Melalui pembentukan BUMDes ini, kaum milenial juga akan terbantu dalam hal pendanaan untuk pengelolaan desa wisata. Baiknya, posisi strategis dalam kelembagaan tersebut diduduki oleh kaum milenial yang dianggap layak dan kompeten. Selain itu, kelembangaan ini juga sepatutnya diisi oleh representasi dari masingmasing banjar untuk menghindari adanya konflik horizontal. Setelah itu, kaum milenial kemudian memetakan setiap potensi wisata yang ada di setiap banjar untuk dikembangkan sesuai dengan segmentasi pasar tanpa mengabaikan aspek keberlanjutan alam dan budaya lokal. Pemetaan ini diharapkan dapat menghasilkan diversifikasi produk wisata yang berbeda di setiap banjar.

Kaum milenial dapat menjadikan hasil penelitian atas pemetaan potensi pariwisata yang dilakukan oleh Situmorang dan Narottama (2019) dalam mengembangkan kepariwisataan di desa mereka seperti dalam tabel 1 di bawah:

Tabel 1. Pemetaan Potensi Pariwisata

\begin{tabular}{|c|l|}
\hline $\begin{array}{c}\text { Nama } \\
\text { Banjar }\end{array}$ & \multicolumn{1}{|c|}{ Atraksi Wisata } \\
\hline Nungnung & $\begin{array}{l}\text { Air Terjun Nunggung, memiliki } \\
\text { kawasan persawahan yang dapat } \\
\text { dikembangkan sebagai daya tarik } \\
\text { wisata berbasis edukasi dan } \\
\text { ekowisata, atraksi buatan Bali } \\
\text { Jhon Swing dan produk Kopi } \\
\text { Luwak. }\end{array}$ \\
\hline Kiadan & $\begin{array}{l}\text { Memiliki jalur trekking, } \\
\text { agrowisata dan wisata edukasi } \\
\text { tentang pengelolaan kopi. }\end{array}$ \\
\hline Pelaga & $\begin{array}{l}\text { Terdapat sebuah jembatan yang } \\
\text { diklaim sebagai jembatan tertinggi } \\
\text { se-Asia Tenggara, yaitu jembatan } \\
\text { Tukad Bangkung } \\
\text { menghubungkan Desa Pelaga } \\
\text { dengan Desa Belok Sidan. }\end{array}$ \\
\hline Pucak & $\begin{array}{l}\text { Jalur trekking sepanjang } 8 \text { km } \\
\text { dengan garis finish di Bedugul, } \\
\text { Tingata edukasi pengelolaan } \\
\text { kotoran sapi sebagai energi }\end{array}$ \\
alternatif, peternakan lebah, Pura \\
Beji.
\end{tabular}




\begin{tabular}{|c|lr|}
\hline Semanik & $\begin{array}{l}\text { Jalur trekking, taman bunga } \\
\text { matahari. }\end{array}$ \\
\hline Tiyingan & $\begin{array}{l}\text { Produk anyaman bamboo untuk } \\
\text { kepentingan sembahyang yang } \\
\text { dapat dijadikan sebagai wisata } \\
\text { edukasi, pengembangan spot foto, } \\
\text { camping ground. }\end{array}$ \\
\hline Auman & $\begin{array}{l}\text { Terdapat sebuah pabrik } \\
\text { pembuatan wine yang dapat } \\
\text { dikembangkan sebagai wine } \\
\text { tourism, agrowisata. }\end{array}$ \\
\hline
\end{tabular}

Sumber : Situmorang dan Narottama (2019)

Pengembangan produk pariwisata yang khas dan unik pada masing-masing banjar sangat diperlukan untuk meningkatkan length of satay wisatawan di Desa Wisata Pelaga. Hal ini tentunya akan berdampak positif terhadap kontribusi pariwisata bagi perekonomian masyarakat lokal. Setelah membangun sinegritas dan melakukan pemetaan serta pengembangan sejumlah daya tarik wisata, saatnya kaum milenial untuk melakukan kegiatan promosi. Di era modernisasi ini, promosi bukan lagi menjadi sesuatu hal yang sulit dan mahal. Kehadiran media digital sangat memudahkan manusia dalam bertukar infomasi dan menjalin komunikasi. Dengan memanfaakan kecanggihan teknologi, kaum milennial Desa Wisata Pelaga seharusnya dapat dengan mudah melakukan promosi terhadap produk pariwisata yang ada di desanya. Pemanfaatan media digital berbasis viral marketing dapat dilakukan sebagai salah satu upaya praktis dan efisien, terlebih Desa Wisata Pelaga selama ini hanya mengandalkan organisasi JED saja dalam memasarkan produk pariwisata mereka.

Promosi digital berbasis viral marketing Desa Wisata Pelaga ini dapat dilakukan dengan beberapa cara, yakni :

1. Membuat satu akun media sosial resmi Desa Wisata Pelaga, baik itu Instagram, Facebook, Twitter, Line, dan sebagainya sebagai media promosi produk wisata, yang mencakup daya tarik wisata, fasilitas pariwisata, fasilitas umum, akomodasi, informasi harga, informasi terkait penyelenggaraan event atau festival, dan lainnya. Kemudian setiap banjar juga membuat akun media sosial sebagai rujukan yang direkomendasikan untuk menjelaskan secara lebih rinci terkait daya tarik wisata dan produk pariwisata yang ada di banjarnya. Akun Desa Wisata Pelaga hanya memosting berbagai produk wisata unggulan di setiap banjar dengan memberi sedikit keterangan pada caption dan tidak lupa memberi tag pada akun media sosial banjar terkait. Akan lebih baik lagi jika setiap akun media sosial ini selalu aktif dalam memosting setiap kegiatan terkait pariwisata, baik itu keunikan budaya, kehidupan sosial masyarakat, kegiatan para wisatawan, kuliner khas, maupun melakukan repost pada setiap foto menarik yang diunggah oleh wisatawan maupun masyarakat ketika berada di Desa Wisata Pelaga atau dapat pula melakukan live streaming;

2. Membuat video promosi di Desa Wisata Pelaga maupun di setiap banjar yang mengangkat segala keunikan, keindahan, dan potensi wisata yang dimiliki. Video ini kemudian diunggah di akun media sosial seperti Instagram, Facebook, dan YouTube. Tidak hanya video promosi, kaum millennial Desa Wisata Pelaga juga dapat membuat beberapa video lucu yang saat ini sedang diminati oleh para pengguna media sosial di desa mereka dengan menyertakan keterangan lokasi pada postingannya. Jika video tersebut menarik dan mendapat perhatian khalayak ramai maka para pengguna media sosial akan banyak melakukan share atau repost ke pengguna lainnya yang tanpa disadari juga merupakan bagian dari promosi desa wisata. Diantara beberapa pengguna media sosial tersebut, pasti akan ada yang tertarik dengan latar dimana video itu direkam sehingga mereka akan berniat untuk berkunjung kesana;

3. Selain memanfaatkan media sosial, kaum milennial Desa Wisata Pelaga juga dapat bergabung dalam komunitas GenPI (Generasi Pesona Indonesia) yang merupakan salah satu program Kementerian Pariwisata. Dalam komunitas ini, kaum millennial dapat mempromosikan desa mereka di website khusus yang telah disediakan yaitu genpi.co baik melalui tulisan, video, maupun live streaming dengan tetap memperhatikan ketentuan yang telah ditetapkan, yakni no hoax, no sara, dan no politic. Website ini akan menjadi platform eletronik yang sangat tepat untuk memasarkan produk pariwisata dan membangun networking dengan sesama kaum millennial lainnya yang menyukai travelling. Bahkan, Kementerian Pariwisata juga menyediakan platform ITX (Indonesia Travel Exchange) yang memberi kesempatan bagi kaum millennial untuk menjual dan memasarkan sendiri segala jenis paket wisata dan produk wisata yang ada di desa mereka. Selain itu, kaum milenial ini juga dapat bekerjasama dengan aplikasi digital Go DeVi (Go Destination Village) yang diprakarsai oleh putera daerah Bali dan baru diluncurkan pada bulan Agustus lalu. Melalui aplikasi ini, kaum milenial dapat memasarkan produk dan paket wisata yang 
terdapat di desa mereka bersama-sama dengan desa wisata lainnya. Hal ini juga dapat mendorong kreativitas kaum milenial untuk terus berinovasi dalam menawarkan produk pariwisata yang berbeda dengan desa lainnya.

4. Agar promosi dan pemasaran Desa Wisata Pelaga semakin viral, kaum milennial desa juga dapat mengundang para youtuber, selebgram, travel vlogger, travel blogger, ataupun seseorang yang memiliki $3 \mathrm{~F}$ (Followers, Fans, Friends) untuk berkunjung ke desa mereka. Hal ini termasuk dalam bagian digital influencer yang merupakan salah satu stretegi komunikasi oleh Kemenpar. Orang-orang tersebut nantinya akan mengunggah foto atau video mereka selama berada di Desa Wisata Pelaga dengan menyertakan komentar yang positif untuk membangun citra destinasi. Atau bahkan, orang tersebut dapat juga melakukan endorse dengan melakukan kompetisi seperti, lomba menulis cerita, fotografi, maupun vlog competition dengan hadiah makan malam bersama di salah satu rumah makan yang ada di Jembatan Bangkung, di Restoran Bagus Agro, atau hadiah menarik lainnya;

5. Membuat tag line Desa Wisata Pelaga yang menjadi ikon utama dalam promosi digital berbasis viral marketing. Misalnya memberi hastag dalam setiap postingan di media sosial, seperti \#AutenthicBali, \#BaliSociety, \#DesaWisataPelaga, \#GenPIPelaga, \#GenPIBali, \#Bali, atau hastag lainnya yang sudah banyak digunakan untuk mendongkrak popularitas. Katakan saja setiap banjar memiliki 50 anggota Seka Teruna Teruni yang secara rutin memosting foto atau video menggunakan hastag sedikitnya sekali dalam seminggu maka akan terdapat 400 postingan yang sangat variatif. Hastag dari setiap postingan ini juga dapat menjadi refrensi bagi calon wisatawan disamping melalui akun media sosial Desa Wisata Pelaga maupun setiap banjar. Selain itu, jumlah teman atau followers di media sosial juga akan sangat memengaruhi promosi berbasi viral marketing di Desa Wisata Pelaga tersebut. Untuk itu, peran kaum milenial yang berurbanisasi lebih diutamakan dalam promosi desa wisata karena jejaring mereka yang lebih luas dan beragam di media sosial. Beberapa dari mereka yang bekerja di hotel, kapal pesiar, restoran, café, bar, dan sebagainya mungkin berteman dengan wisatawan mancanegara repeater.

6. Memanfaatkan wisatawan untuk turut mempromosikan Desa Wisata Pelaga juga merupakan salah satu cara yang dapat dilakukan. Dengan meminta mereka untuk mengunggah foto atau video dengan menggunakan hastag yang telah ditetapkan dengan menambahkan lokasi dan caption positif akan membantu promosi desa. Sebagai feedback, wisatawan tersebut akan diberi diskon maupun souvenir sebagai kenang-kenangan. Baiknya, wisatawan yang dipilih ialah mereka yang memiliki $3 \mathrm{~F}$ di media sosial.

\section{KESIMPULAN}

Kesenjangan perekonomian yang terjadi di Kabupaten Badung terjadi karena adanya konsentrasi pusat pertumbuhan ekonomi di wilayah selatan sebagai sentra pariwisata. Sementara wilayah utara yang ditetapkan sebagai kawasan pertanian terintegrasi tidak mengalami perkembangan yang cukup signifikan layaknya wilayah selatan. Implikasinya, kaum milenial dari wilayah utara, khususnya Desa Wisata Pelaga kerap melakukan praktik urbanisasi ke wilayah selatan sehingga partisipasi dan keterlibatan mereka dalam pengembangan kepariwisataan sangat minim. Rendahnya partisipasi kaum milanial dalam pengelolaan desa wisata juga disebabkan karena adanya konsepsi ageism yang ditujukan oleh kalangan senior kepada mereka, kaum milenial terjebak dalam bingkai konsumerisme global karena telah terperangkap dalam arus modernitas, adanya kekeliruan dalam menafsirkan pekerjaan. Hal ini sangat disesalkan mengingat salah satu kendala dalam pengelolaan desa wisata adalah minimnya kualitas sumber daya manusia yang berkualitas. Sehingga peran kaum milenial yang kaya akan inovasi dan kreativitas sangat dibutuhkan dalam pengelolaan desa wisata. Adapun langkah yang dapat dilakukan oleh kaum milenial dalam menunjukkan eksistensinya dalam pengelolaan desa wisata adalah dengan mendirikan BUMDes sebagai organisasi pengelola desa wisata. Hal ini diperlukan untuk membantu kaum milenial maupun pihak desa wisata mengatasi kendala terkait pendanaan dengan memanfaatkan anggaran dana desa. Setelah membentuk suatu lembaga yang terintegrasi, kaum milenial baiknya melakukan pemetaan dan pengembangan terhadap sejumlah potensi pariwisata pada masing-masing banjar dengan mengutamakan aspek diversifikasi. Pada tahap pemasaran dan promosi, kaum milenial yang telah melek teknologi ini dapat memanfaatkan media digital sebagai sarana untuk memperkenalkan dan menawarkan produk pariwisata mereka ke khalayak ramai. 


\section{DAFTAR PUSTAKA}

Achyunda, Reva, Roro Retno Eva, Itca Istia Wahyuni. 2017. Narasi sebagai StrategiViraMarketing pada Akun Foodstagram @Makanpakereceh. E - Proceeding of Management Volume 4 Nomor 2, Halaman 1950-1958. Bandung : Telkom University.

Agunggunanto, dkk. 2016. Pengembangan Desa Mandiri melalui Pengelolaan Badan Usaha Milik Desa (BUMDes). Jurnal Dinamika Ekonomi dan Bisnis, Vol. 13, No. 1, Hal. 67 81.

Andini, Natasya Putri, Suharyono, Sunarti. 2014. Pengaruh Viral Marketing Terhadap Kepercayaan Pelanggan dan Keputusan Pembelian (Studi Pada Mahasiswa Ilmu Administrasi Universitas Brawijaya Angkatan 2013 yang Melakukan Pembelian Online Melalui Media Sosial Instagram). Jurnal Administrasi Bisnis (JAB), Volume 11, Nomor 1, Halaman 1-6. Malang : Universitas Brawijaya.

Anom, I Putu, dkk. 2015. Laporan Akhir Kajian Pengembangan Desa Wisata di Desa Wisata di Kabupaten Badung. Badung : Pemerintah Kabupaten Badung.

Anom, I. P., Suryasih, I. A., Nugroho, S., \& Mahagangga, I. G. A. O. (2017). Turismemorfosis: Tahapan selama seratus tahun perkembangan dan prediksi pariwisata Bali. Metamorfosis Pariwisata, Tantangan Membangun Pariwisata Berkelanjutan di.

Anonim. Peraturan Bupati Badung Nomor 47 Tahun 2010 tentang Penetapan Kawasan Desa Wisata di Kabupaten Badung.

Anonim. Peraturan Daerah Kabupaten Badung Nomor 26 Tahun 2013 Tentang Rencana Tata Ruang Wilayah Kabupaten Badung Tahun 2013 2033.

Anonim. Surat Edaran Kadisparda Provinsi Bali Nomor 556/317/I/DISPAR tentang Pengembangan 100 Desa Wisata di Provisi Bali 2014-2018. Denpasar : Dinas Pariwisata Daerah Kabupaten Badung.

Anonim. Undang-Undang Nomor 6 Tahun 2014 Tentang Desa.

Anonim. 2017. Pengembangan Desa Wisata : Desa Membangun Indonesia. Disampaikan oleh Tim Percepatan Wisata Desa dan Kota : Jakarta.

Anonim. 2017. The Urban Middle-Class Millenials Indonesia : Financial and Online Behavior. Jakarta Selatan : PT Alvara Strategi Indonesia.
Bungin, H.M Burhan. 2007. Penelitian Kualitatif Edisi Kedua. Jakarta : PT Prenada Media Group.

Frey, William H. 2018 The Millenial Generation : A Demographic Bridge to America's Diverse Future. Dipulikasikan secara online : https://www.brookings.edu/wp content/uploads/2018/01/2018janbrookin smetromillennials-a-demographic-bridge-to americas-diversefuture.pdf (Diakses pada tanggal 26 April 2019, Pukul 10.29 WITA)

Kurniawan, Borni. 2015. Desa Mandiri Desa Membangun. Jakarta : Kementerian Desa, Pembangunan Daerah Tertinggal, dan Transmigrasi Republik Indonesia.

Kusmayadi dan Sugiarto, E., 2000, Metodologi Penelitian dalam Bidang Kepariwisataan, Jakarta: PT. Gramedia Pustaka Utama.

Mahagangga, I. G. A. O., Sos, S., Anom, I. P., Par, M., \& Suryasih, I. A. KAJIAN PENGEMBANGAN DESA WISATA DI KABUPATEN BADUNG.

Moleong, Lexy. J. 2014. Metodologi Penelitian Kuantitatif Edisi Revisi. Bandung : PT Remaja Rosdakarya.

Muhadjir, Noeng. 1996. Metodologi Penelitian Kualitatif Edisi Ke - 3. Yogyakarta : Rake Sarasain.

Nalayani, Ni Nyoman Ayu Hari. 2016. Evaluasi dan Strategi Pengembangan Desa Wisata di Kabupaten Badung, Bali. Jurnal JUMPA 2 (2) : 189 - 198.

Nugroho, Saptono, A.A Ngurah Palguna. 2016. Generasi Mudal dalam Praktik Desa Wisata di Kabupaten Badung. Dalam Suryawan, Ida Bagus, Ida Ayu Suryasih, I Putu Anom (Ed.) Perkembangan dan Pengembangan Desa Wisata : 111 - 127. Depok : Herya Media.

Nuryanti, Wiendu. 1993. Concept, Perspective, and Challenges. Laporan Konferensi Internasional mengenai Pariwisata Budaya. Yogyakarta: Gadjah Mada University Press. 1993.

Prasetyani, Retnaayu. 2017. Generasi Millenial dan Inovasi Jejaring Demokrasi Teman Ahok. Jurnal Polinter Prodi Ilmu Politik Fisip UTA'45 3 (1) : 44 - 52.

Putra, Yanuar Surya, 2016. Theoritical Review : Teori Perbedaan Generasi. Jurnal Among Makarti 9 (18) : 123 - 134.

Saragih, Wiwin Roy Jaya, I Made Sendra, I GPB. Sasrawan Mananda. Karakteristik dan Motivasi Wisatawan Ekowisata di Bali (Studi Kasus di Jaringan Ekowisata Desa). Jurnal IPTA 3 (1) : $17-21$.

Sanjiwani, Putri Kusuma. 2015. Kebijakan Pemerintah Terhadap Kelembagaan Kelompok Sadar Wisata (Pokdarwis) dalam Pengembangan Desa Wisata di Provinsi Bali. Arida, I Nyoman Sukma, Ni Ketut Arismayanti (Ed. 
Kebijakan dan Paradigma Pariwisata. Denpasar : Cakra Press.

Situmorang, James R. 2010. Pemasaran Viral - Viral Marketing. Jurnal Administrasi Bisnis, Volume 6, Nomor 1, Halaman 59-71. Bandung : Universitas Parahyangan.

Situmorang, Fransisco, Nararya Narottama. 2019. Peran Kaum Milenial dalam Pengembangan Digital Nomadic Tourism sebagai Badan Usaha Milik Desa : Studi Kasus di Desa Wisata Pelaga Kabupaten Badung Bali. Disampaikan dalam Seminar Riset Terapan Hospitaliti dan Kepariwisataan Indonesia 2019 di STP Bali pada tanggal 11 Juli 2019.

Sugiyono. 2013. Metode Penelitian Kuantitatif, Kualitatif, dan R\&D. Badung : CV Alfabeta.

Suryawan, Ida Bagus, Ida Ayu Suryasih, I Putu Anom. 2016. Perkembangan danPengembangan Desa Wisata. Bogor : Herya Media Depok. 